The Hundred Years WaR 


\title{
The Hundred Years War
}

\author{
AnNe Gurry \\ Lecturer in History \\ University of Reading
}


ISBN 978-0-333-53176-1

DOI 10.1007/978-1-349-22711-2

(C) Anne Curry 1993

All rights reserved. For information, write:

Scholarly and Reference Division,

St. Martin's Press, Inc., 175 Fifth Avenue,

New York, N.Y. 10010

First published in the United States of America in 1993

ISBN 978-0-312-09142-2 (hardcover)

ISBN 978-0-312-09141-5 (paperback)

Library of Congress Cataloging-in-Publication Data

Curry, Anne.

The Hundred Years War / Anne Curry.

p. $\mathrm{cm}$.

Includes bibliographical references and index.

ISBN 978-0-312-09142-2 (cloth).--ISBN 978-0-312-09141-5 (pbk.)

1. Hundred Years' War, 1339-1453. 2. France-History,

Military-1328-1589. 3. France-Kings and rulers-Genealogy.

4. France-Foreign relations-Great Britain. 5. Great Britain-

-Foreign relations-France. I. Title.

DC96.C87 1993

$944^{\prime} .025-\mathrm{dc} 20$ 


\section{CONTENTS}

Preface vii

Maps

English lands in France before 1337

viii

English lands by the Treaty of Brétigny, 1360

ix

The extent of English control of France in the fifteenth century

The European context

$\mathbf{x}$

$\mathrm{xi}$

Genealogical Tables

The French succession from 1180 to 1350 xii

French kings from 1350 to 1483 xiii

English kings from 1327 to 1483 xiv

Introduction

1 The Hundred Years War and Historians 6

$\begin{array}{ll}\text { Contemporary chroniclers } & 6\end{array}$

The sixteenth century $\quad 16$

The seventeenth and eighteenth centuries $\quad 19$

The nineteenth century $\quad 23$

$\begin{array}{ll}\text { The twentieth century } & 26\end{array}$ 
2 Origins and Objectives: Anglo-French Conflict in the Fourteenth Century

Feudal origins

Dynastic origins 44

$1340-1369 \quad 58$

1369-1399 74

3 New Wars or Old? Anglo-French Conflict in the Fifteenth Century

The reign of Henry IV

Henry $V$ and the conquest of Normandy

The Treaty of Troyes

1422-1451

The end of the Hundred Years War

4 The Wider Context

The European states and the war

Conclusion

Notes

Select Bibliography

Glossary

184

Index 


\section{PREFACE}

This book owes much to the hard work and enthusiasm of fellow historians on both sides of the Channel. In particular, I would like to thank Professor J. S. Roskell for first alerting me to the fascination of the subject, and Professor G. T. Allmand and Dr A. J. Pollard for guiding my research. Of my colleagues, Professors M. D. Biddiss and B. R. Kemp deserve special mention for their helpful advice in the preparation of this book. John and Tom have had to put up with much neglect on the home front, but have never ceased to provide support and encouragement. To them I offer both my love and my gratitude. 


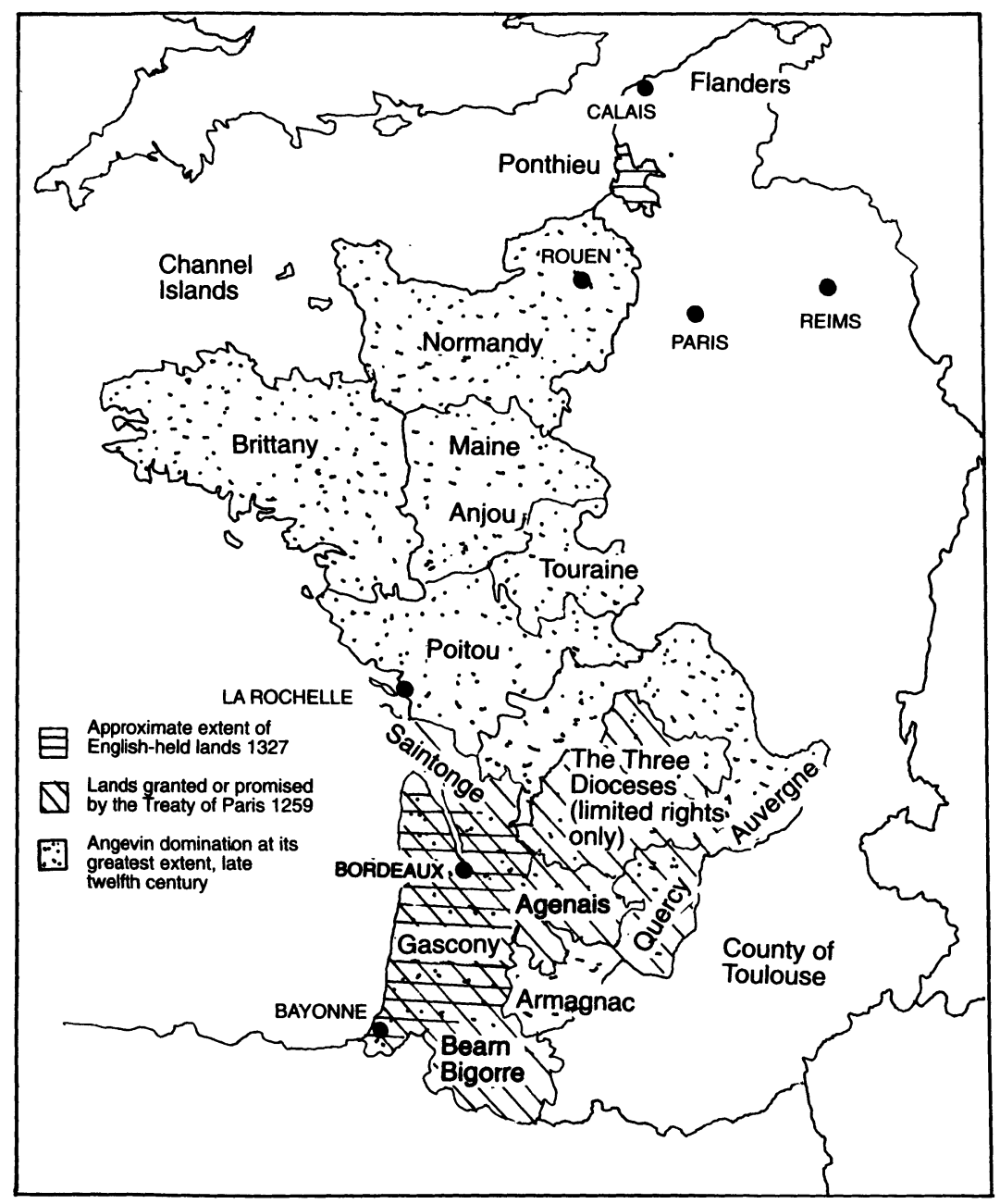

English lands in France before 1327 


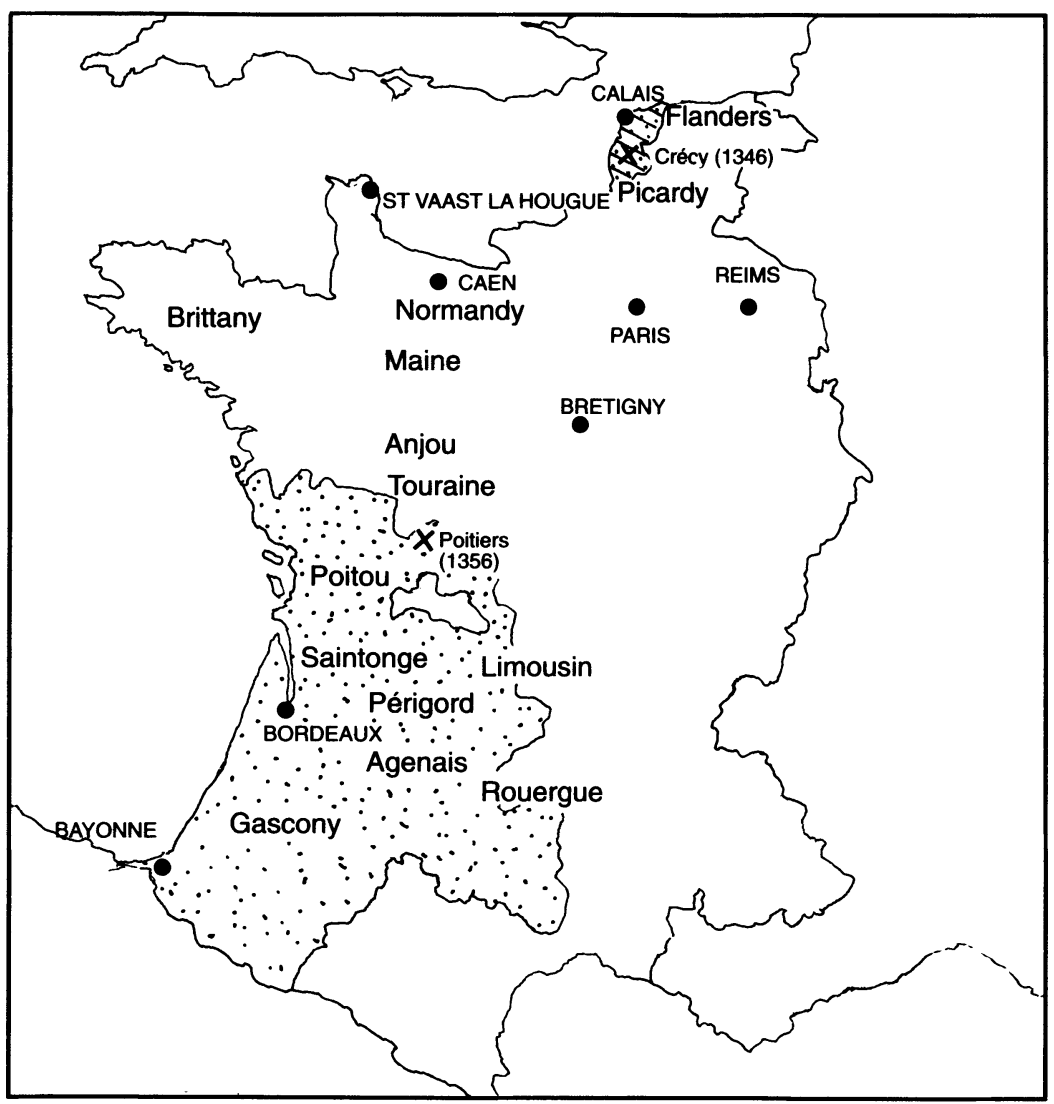

English lands by the Treaty of Brétigny, 1360 


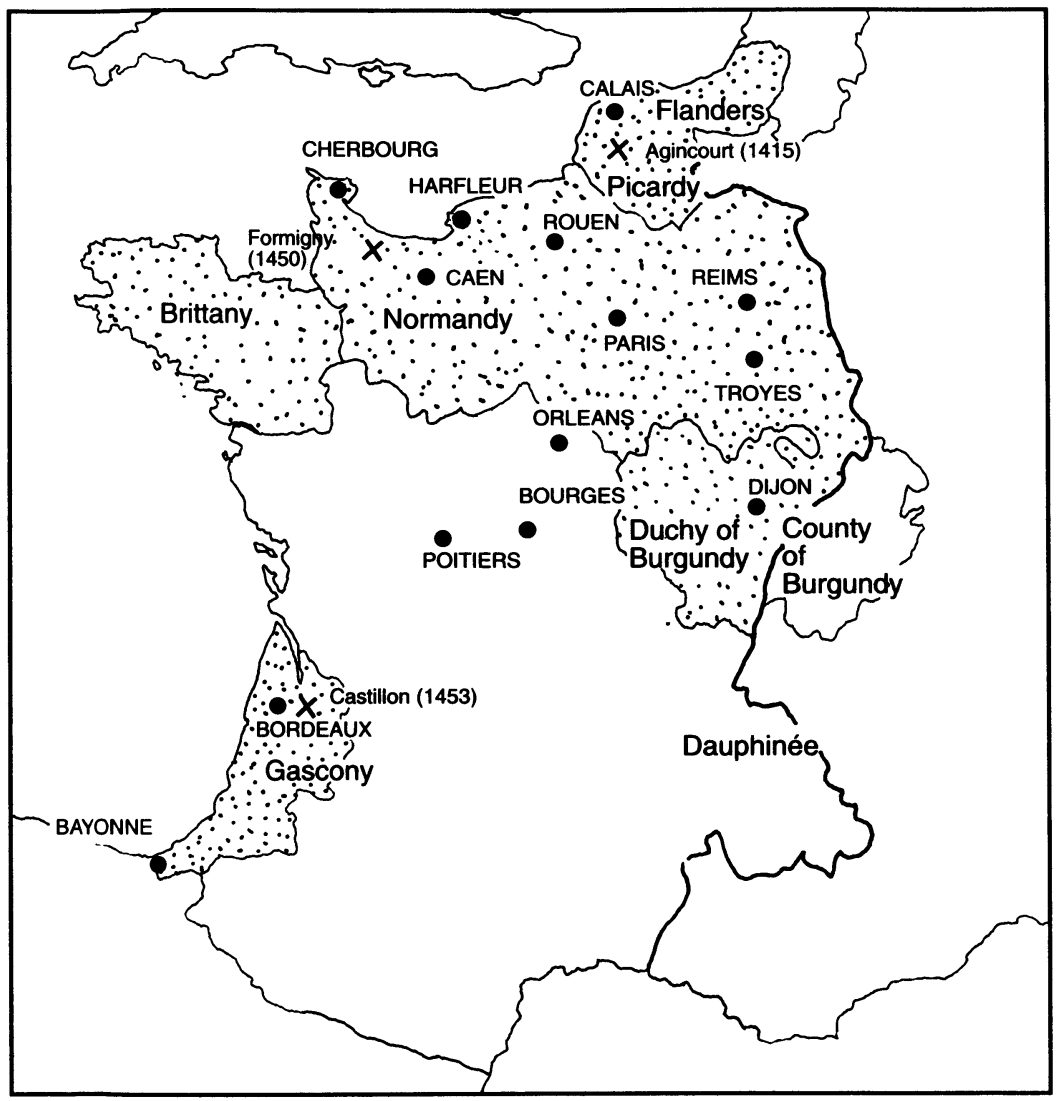

The extent of English control of France in the fifteenth century 


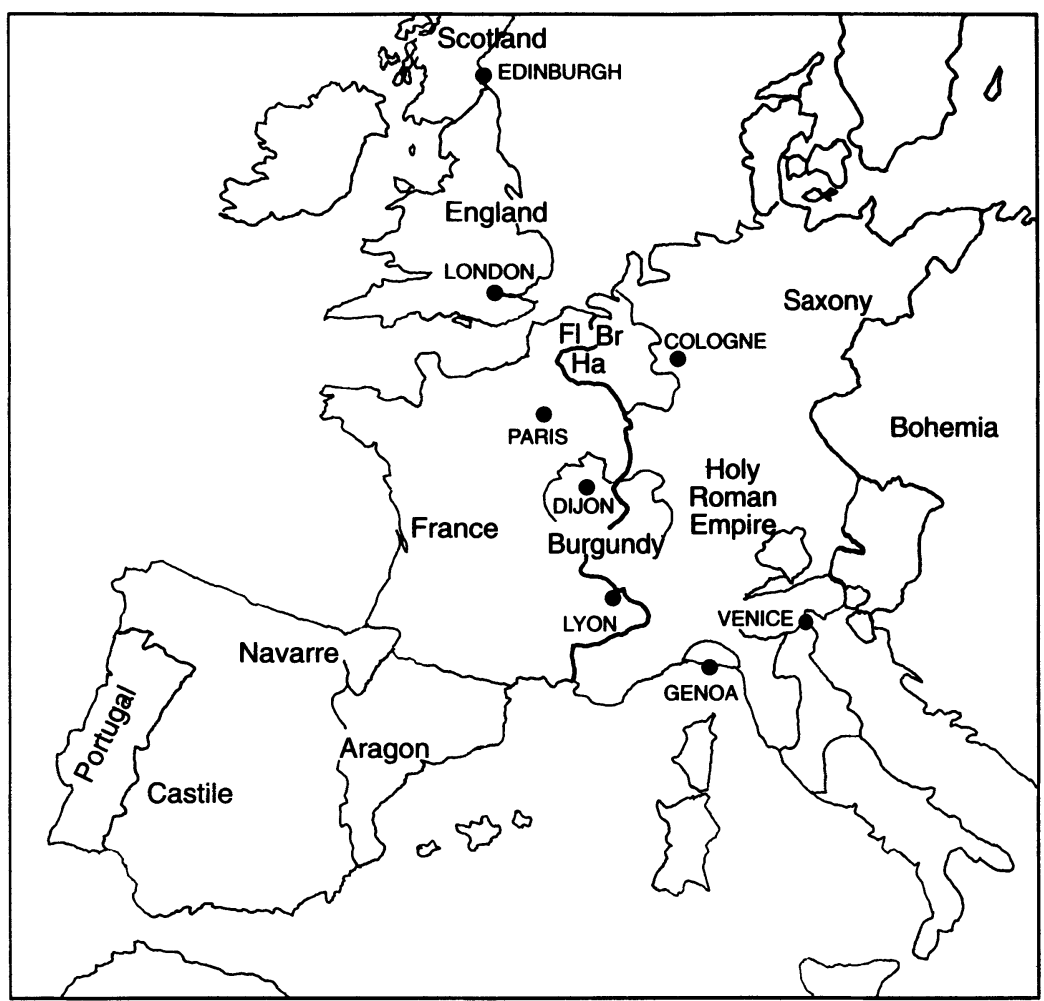

The European context

Fl - Flanders

$\mathrm{Br}$ - Brabant

$\mathrm{Ha}$ - Hainault

- - western boundary of imperial authority 
Genealogical Tables

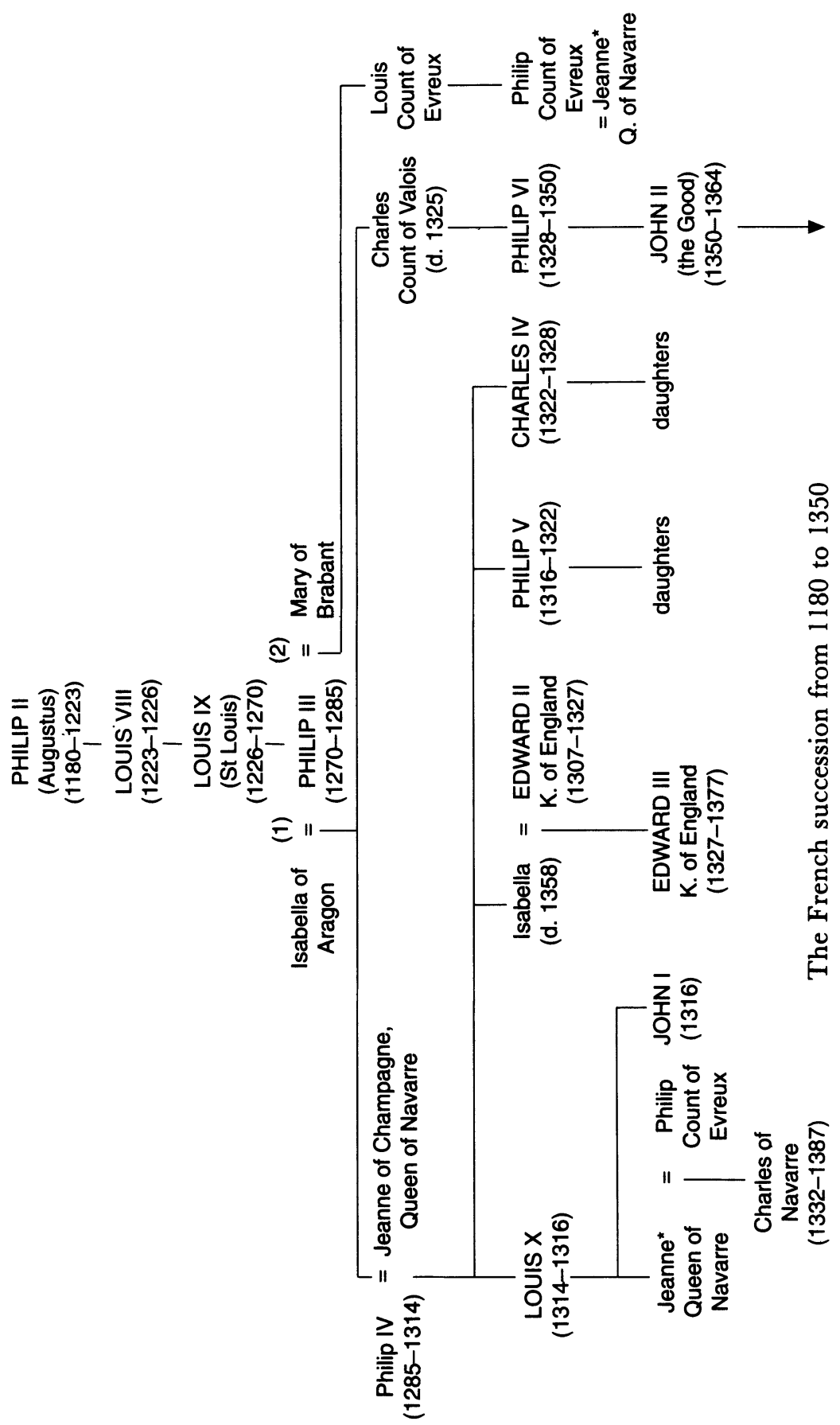


Genealogical Tables

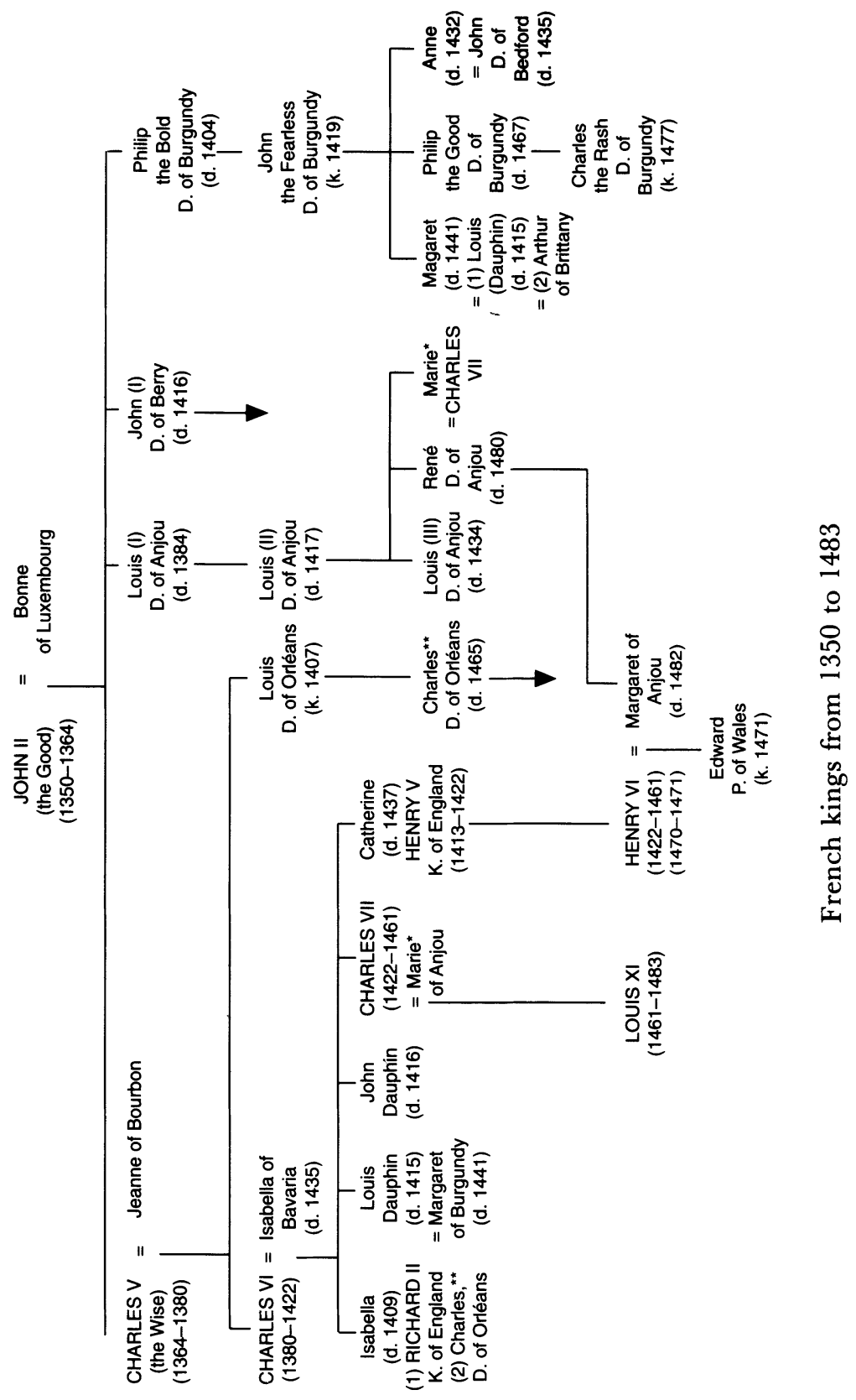




\section{Genealogical Tables}

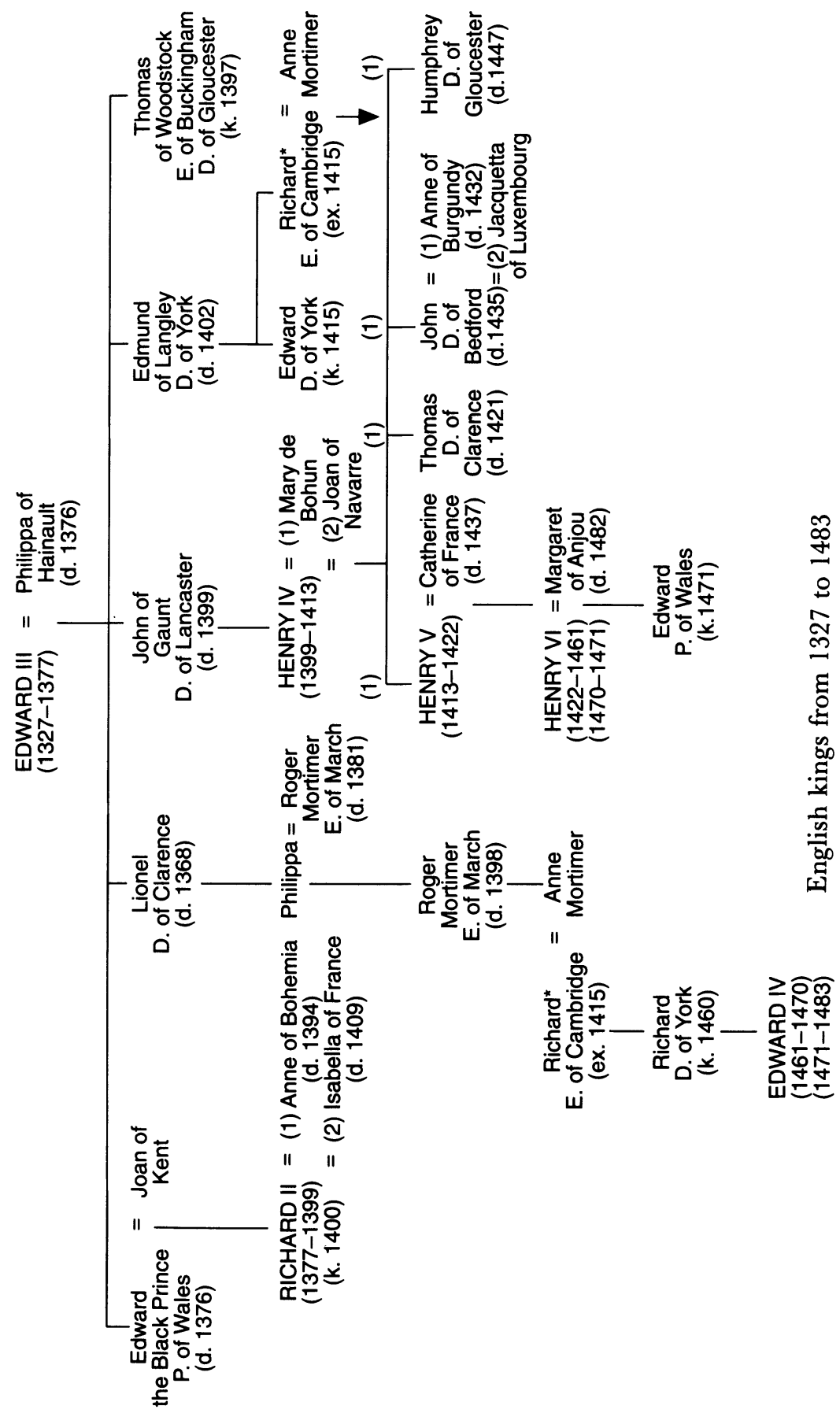

